Historia i Polityka

Półrocznik poświęcony myśli politycznej i stosunkom międzynarodowym

Nr $10(17) / 201375-93$

DOI: http://dx.doi.org/10.12775/HiP.2013.013

Tomasz Koziełło (Uniwersytet Rzeszowski)

\title{
Stosunki polsko-amerykańskie a wojna w Iraku w koncepcjach politycznych LPR
}

\author{
Polish-American relations and Iraq War \\ in political conceptions of Liga Polskich Rodzin
}

Liga Polskich Rodzin (League of Polish Families) had two points of view toward policy of the United States of America. On the one hand leaders of party thought, that alliance with the USA should be one of the most important principles of Polish foreign policy. Theirs attitude was connected with conviction, that partnership and good relations with American power Poland could protect its sovereignty and territorial integrity in opposite German revisionism and Russian aspiration for rebuilding former political influence in Eastern Europe. Another reason conceptions for Polish-American cooperation was conviction, that this alliance let Poland receive more economical benefits from the USA than through integration with European Union. The United States of America might be better alternative for economical and social development of Polish country than EU, because, according to attitude of LPR, American power always helps its allies, without forcing on them its diktat in internal and foreign policy. Third reason of pro-American point of view in political thought of LPR was hope, that position main American ally in continental part of Europe could let Poland become one of the more important countries in this part of the world or obtain more better conditions during negotiation with EU.

On the other hand leaders of LPR knew, that more of them ideas was wishful thinking, which not to be connected with reality and main targets of American foreign policy. As a proof for it showed bad treatment of Poland and Polish citizens by the USA and disregarding interests of Polish state. These activities would be using Polish military forces in operations in Afganistan and Iraq without any compensations, for example financial help, political support in different international troubles or liquidation visa for Polish citizens. Declared ideas of Polish-American cooperation was mixed with critics policy of the USA, but LPR always stood on position supporting American power, thinking, that alliance with them was more belter solution than integrity with EU.

Słowa kluczowe: interwencja w Iraku, Polsko-Amerykańska współpraca wojskowa, myśl polityczna nacjonalizmu

Keywords: intervention in Iraq, Polish-American military cooperation, nationalist political thought 


\section{Wstęp}

W nocy z 19 na 20 marca 2003 roku wojska amerykańskie rozpoczęły atak na Irak w ramach operacji „Iracka Wolność”. Celem tych działań miało być opanowanie całego kraju, obalenie rządzącego nim Saddama Husajna i jego reżimu oraz ustanowienie demokratycznych rządów, opierających się na proamerykańskich irackich politykach emigracyjnych. Przeprowadzenie inwazji było poprzedzone wielomiesięcznymi zabiegami dyplomatycznymi kierujących polityką zagraniczną Stanów Zjednoczonych prezydenta George'a W. Busha i sekretarza stanu Colina Powella o uznanie Iraku pod władzą Husajna za jedno z najbardziej niebezpiecznych dla bezpieczeństwa i pokoju światowego państw, posiadającego broń masowej zagłady i wspierającego międzynarodowe organizacje terrorystyczne, które trzeba unieszkodliwić. Starania amerykańskich decydentów nie zostały uwieńczone powodzeniem - rezolucja nr 1441 Rady Bezpieczeństwa Organizacji Narodów Zjednoczonych z 8 listopada 2002 roku zobowiązywała Irak do udostępnienia komisji międzynarodowej całej infrastruktury celem sprawdzenia, czy nie produkuje się tam broni masowego rażenia, jednak większość państw Rady była przeciwna użyciu sił zbrojnych nad Zatoką Perską. Mimo dyplomatycznego niepowodzenia Stany Zjednoczone i popierająca je Wielka Brytania zaczęły gromadzić wojska na granicy z Irakiem, jednocześnie próbując zmusić RB ONZ do wyrażenia zgody na zbrojną interwencję pod pretekstem, że Irak sabotuje prace komisji międzynarodowej i ukrywa przed nią silny arsenał broni masowego rażenia. Kiedy te zabiegi okazały się nieskuteczne, USA podjęły decyzję o ataku wojskowym na Irak. Wojna zakończyła się po niecałych czterech tygodniach zajęciem w dniach 11-14 kwietnia ostatnich ważnych punktów oporu - Kirkuku, Mosulu i Tikritu. Po zwycięskiej wojnie władze amerykańskie ustanowiły podział Iraku na strefy okupacyjne, likwidując resztki armii irackiej i przygotowując się do wprowadzenia systemu demokratycznego w państwie ${ }^{1}$.

Władze polskie od samego początku były pozytywnie nastawione do zamierzeń amerykańskich względem Iraku. Prezydent Aleksander Kwaśniewski oraz kierujący rządem premier Leszek Miller uważali, że zlikwidowanie niebezpieczeństwa, jakie stanowił reżim Husajna, powinno być jednym z najważniejszych celów polityki międzynarodowej, ponieważ iracki dyktator od ponad 10 lat stanowił czynnik destabilizujący sytuację na Bliskim Wschodzie i zagrażał bezpieczeństwu

1 Więcej na ten temat zob. J. Kiwerska, Świat w latach 1989-2004: Wydarzenia-konflikty-procesy, Poznań 2005, s. 286-322. 
nie tylko państw sąsiednich ale również krajom cywilizacji zachodniej. Oskarżenia, jakie względem Iraku formułowali amerykańscy decydenci umacniały stanowisko władz Rzeczypospolitej dotyczące bezwzględnego poparcia działań Stanów Zjednoczonych nad Zatoką Perską. W styczniu 2003 roku podczas spotkania z Bushem w Waszyngtonie Kwaśniewski zadeklarował poparcie polityczne Polski dla interwencji USA w Iraku, zaś miesiąc później uczynił to Miller. Jednocześnie rząd Polski, wraz z rządami siedmiu innych państw europejskich (Czech, Danii, Hiszpanii, Portugalii, Węgier, Wielkiej Brytanii i Włoch) wystosował 30 stycznia 2003 roku list, wyrażający poparcie dla amerykańskiej polityki w Iraku. Dnia 17 marca prezydent Kwaśniewski, na wniosek Rady Ministrów, zadecydował o zgodzie na użycie Polskiego Kontyngentu Wojskowego celem wyegzekwowania na Iraku realizacji rezolucji nr 1441, co skutkowało tym, że w operacji wojskowej wzięła udział jednostka GROM, przeprowadzając kilka misji dywersyjnych. Natomiast kiedy po wojnie Polska objęła dowództwo jednej ze stref okupacyjnych (centralno-południowej ze stolicą w Karbali), polskie władze wysłały tam kontyngent wojskowy w sile ponad 2300 żołnierzy, będący trzecią pod względem wielkości (po Stanach Zjednoczonych i Wielkiej Brytanii) armią okupacyjną. Ostatecznie podczas pięciu lat pobytu w Iraku (2003-2008) w Polskim Kontyngencie Wojskowym służyło łącznie około 9000 żołnierzy, z czego zginęło 22. Koszt utrzymania PKW wyniósł ponad 1 mld złotych, co stanowiło około $1 \%$ budżetu Ministerstwa Obrony Narodowej za ten okres².

Udział wojsk polskich w operacji wojskowej i stabilizacyjnej w Iraku poparły partie tworzące rząd Millera - Sojusz Lewicy Demokratycznej, Unia Pracy i Partia Ludowo-Demokratyczna a także część ugrupowań opozycyjnych, m.in. Platforma Obywatelska i Prawo i Sprawiedliwość. Przeciw były Samoobrona RP i Liga Polskich Rodzin, natomiast Polskie Stronnictwo Ludowe podzieliło się w tej kwestii. Ostatecznie podczas debaty sejmowej, która odbyła się 26 marca 2003 roku za poparciem decyzji prezydenta i rządu głosowało 328 posłów, przeciwnych było 71, zaś 38 wstrzymało się od głosu. Mając poparcie większości parlamentarnej władze państwa polskiego mogły zrealizować swój cel, jakim było włączenie się militarne w okupację i stabilizację Iraku. Niemniej jednak udział polskich żołnierzy w misji irackiej stanowił cały czas powód do krytykowania i atakowania rządzących ze

\footnotetext{
2 Zob. szerzej: M. Wągrowska, Udziat Polski w interwencji zbrojnej i misji stabilizacyjnej w Iraku, Centrum Studiów Międzynarodowych, http://csm.org.pl/fileadmin/files/Biblioteka_ CSM/Raporty_i_analizy/2004/Maria\%20W\%C4\%85growska_Udzia\%C5\%82\%20Polski\%20 w\%20interwencji\%20zbrojnej\%20i.pdf; D. Materniak, J. Rutkowska, M. P. Żukowska, Irak klęska czy zwycięstwo Polski?, Portal Spraw Zagranicznych, http://www.psz.pl/tekst-14450/Irak-kleska-czy-zwyciestwo-Polski [odczyt: 15 VII 2013].
} 
strony LPR, która nie zmieniła swojego stanowiska nawet po zmianie koalicji rządzącej w 2005 roku. Liga, powstałe w 2001 roku ugrupowanie odwołujące się m. in. do ideałów Narodowej Demokracji, sprzeciwiała się wysłaniu PKW na Bliski Wschód a jej przywódcy wielokrotnie dawali to do zrozumienia, zarówno podczas wystąpień sejmowych, jak i na łamach mediów.

Artykuł niniejszy stanowi analizę stosunku Polski do Stanów Zjednoczonych przez pryzmat wojny w Iraku 2003 roku w koncepcjach politycznych Ligi Polskich Rodzin. Składa się z dwóch części. Pierwsza z nich omawia ogólny stosunek LPR do państwa amerykańskiego, postulaty, jakie wysuwali względem niego oraz jej ocenę stanu faktycznego relacji polsko-amerykańskich. Część druga natomiast dotyczy zagadnienia wojny w Iraku i okupacji tego państwa. Jej treścią jest omówienie stanowiska LPR odnośnie samej wojny i udziału w niej polskich żołnierzy, wyjaśnienie własnego stanowiska oraz postulowanych relacji polsko-amerykańskich, jakie muszą zaistnieć wskutek zaangażowania militarnego Rzeczypospolitej na Bliskim Wschodzie.

\section{Stosunek LPR do Stanów Zjednoczonych}

Liga Polskich Rodzin prezentowała się jako ugrupowania silnie proamerykańskie i głównego zwolennika bliskich związków Polski ze Stanami Zjednoczonymi. W wypowiedziach przywódców partyjnych wielokrotnie można było zauważyć, że USA traktowane są jak sojusznik i partner państwa polskiego, z którym należy mieć jak najlepsze relacje w kwestiach politycznych, gospodarczych i militarnych. Podkreślano, że Polska powinna, w ramach swojego dobrze pojętego interesu państwowego i narodowego, lojalnie współpracować z amerykańskim mocarstwem, popierać jego politykę i powstrzymywać się od jakichkolwiek antyamerykańskich działań w środowisku międzynarodowym. Uznawano bowiem, że tylko sojusz, stosunki partnerskie i przyjaźń polsko-amerykańska pozwolą na realizację przez Rzeczpospolitą swoich celów strategicznych. Do nich zaliczano: 1) obronę polskiego terytorium i polskiej niepodległości przed zagrożeniem zewnętrznym, 2) rozwój gospodarczy i podniesienie poziomu życia społecznego oraz 3) wzrost pozycji państwa polskiego na kontynencie europejskim³. Zygmunt Wrzodak, przewod-

3 Program Polski nowoczesnej, rozmowa z M. Kotlinowskim, Racja Polska (RP), 13-20 IV 2003, nr 7-8, s. 7; Nie jesteśmy chtopcem do bicia, rozmowa z M. Giertychem, RP, 1-8 VI 2003, nr 14-15, s. 26; R. Giertych, To, co obiecaliśmy, zrealizujemy, Myśl Polska (MP), 26 III 2006, nr 13, s. 5; wystąpienie M. Giertycha, IV kad., pos. 40 Sejmu z 22 I 2003, Sejm RP, http://orka2.sejm. gov.pl/Debata4.nsf; wystąpienie J. Dobrosza, IV kad., pos. 67 Sejmu z 21 I 2004, Sejm RP, http:// 
niczący Rady Politycznej (2001-2005) powiedział: „Powinniśmy współpracować z Ameryką". Natomiast zdaniem Romana Giertycha, przewodniczącego Kongresu (2001-2006) i prezesa Zarządu Głównego (2006-2007): „USA to jest nasz najbliższy sojusznik"4.

Jako pierwszą z przyczyn, dla których państwo polskie powinno ściśle współpracować ze Stanami Zjednoczonymi, wymieniano obronę przez USA polskiej integralności terytorialnej i suwerenności. Przywódcy Ligi podkreślali niebezpieczeństwo grożące Polsce ze strony Niemiec oraz Rosji. Uważali, że polityka rewizjonistyczna zachodniego sąsiada, mająca poparcie w wielu krajach Unii Europejskiej, mogła doprowadzić do zmuszenia Polski, aby stopniowo zrzekła się suwerenności nad zachodnimi ziemiami, zdobytymi po II wojnie światowej. Z drugiej strony obawiano się Rosji i wykorzystania przez jej władze uzależnienia Polski od dostaw surowców energetycznych, zwłaszcza gazu ziemnego i ropy naftowej po to, by narzucać jej swoje interesy. Dlatego też w Stanach Zjednoczonych widziano oparcie dla Rzeczypospolitej w konfrontacji z oboma sąsiadami. Liderzy LPR stali na stanowisku, że USA, jeśli z kimś zawrą sojusz, to zawsze bronią go przed niebezpieczeństwem utraty suwerenności i niepodległości, wyrażali więc nadzieję, że tak będzie i w przypadku Polski. Jako przykład przytaczali stanowisko prezydenta Woodrowa Wilsona w czasie I wojny światowej, dzięki któremu Polacy po zaborach odzyskali niepodległość a także politykę administracji amerykańskiej w czasie II wojny światowej, która uchroniła Polskę przed włączeniem do ZSRR. W przeciwieństwie do Niemiec, Rosji czy UE przywódcy ugrupowania nie mieli oporów przed wyrażaniem lojalnego poparcia dla polityki amerykańskiej, twierdząc, że Stany Zjednoczone nie wykorzystają tego dla narzucenia Polsce swoich wpływów i zwasalizowania jej. Uważali bowiem, że USA nigdy nie wtrącają się w wewnętrzne sprawy żadnego z państw, chyba, że te państwa zagrażają ich bezpieczeństwu. Stąd też popierano obecność militarną Stanów Zjednoczonych w Europie jako gwarancję pokoju, bezpieczeństwa i integralności terytorialnej państw przed jakąkolwiek próbą jej naruszenia oraz polityczne wpływy na Starym Kontynencie, dzięki którym liczono na możliwość realizacji przez Polskę swoich interesów politycznych i gospodarczych 5 . Janusz Dobrosz, przewodniczący Rady Politycznej

orka2.sejm.gov.pl/Debata4.nsf; wystąpienie J. Dobrosza, IV kad., pos. 96 Sejmu z 21 I 2005, Sejm RP, http://orka2.sejm.gov.pl/Debata4.nsf; wystąpienie J. Dobrosza, V kad., pos. 41 Sejmu z 11 V 2007, Sejm RP, http://orka2.sejm.gov.pl/Debata5.nsf [odczyt 3-7 II 2011].

4 Wystąpienie Z. Wrzodaka, IV kad., pos. 65 Komisji Obrony Narodowej (KON) z 9 V 2003, Sejm RP, http://orka.sejm.gov.pl/SQL.nsf/Main4?OpenForm\&OBN; [odczyt 8 II 2011]; R. Giertych, To, co obiecaliśmy..., s. 5.

5 Nie jesteśmy chtopcem..., s. 26; J. M. Jackowski, PAX Americana, RP, 15 VI 2003, nr 16, 
(2005-2008) powiedział: „Naszym interesem jest, żeby Stany Zjednoczone twardo, jednoznacznie militarni były obecne w Europie”. Natomiast Maciej Giertych, wiceprzewodniczący Rady Politycznej (2001-2010) napisał o stosunkach z USA: "Jesteśmy sojusznikami, bo nadal boimy się nie tylko Rosji, ale także Niemiec"6.

Drugą przyczyną dobrych stosunków polsko-amerykańskich miały być sprawy gospodarcze. Stany Zjednoczone uważane były przez przywódców LPR za jeden z najbardziej rozwiniętych ekonomicznie krajów świata, mający największy wpływ na gospodarkę globalną. $Z$ tego względu darzono je poważaniem i podziwiano, jako państwo, które ma najlepszy system gospodarczy na świecie: wolny rynek, niskie podatki, politykę sprzyjającą przedsiębiorcom. Uważano, że bliskie relacje z amerykańskim mocarstwem mogą przyczynić się do poprawy położenia ekonomicznego i społecznego Polski. Widziano to w udzieleniu przez Stany Zjednoczone odpowiedniego wsparcia finansowego i materialnego dla polskiej gospodarki, zacieśnieniu wymiany handlowej, utrzymaniu przez USA klauzuli najwyższego uprzywilejowania dla Polski i udostępnieniu jej części technologii dla rozwinięcia różnych sektorów polskiej wytwórczości. Niemniej ważną rolę odgrywał amerykański przykład rozwoju gospodarczego. Uważano, że skoro Stany Zjednoczone mogły zostać potęgą gospodarczą, więc Polska powinna wzorować się na nich i, postępując podobnie, wyjść z zacofania ekonomicznego i osiągnąć odpowiedni poziom gospodarczy, dający większe możliwości społeczeństwu na polepszenie swojego statusu materialnego. Państwo amerykańskie traktowano jako alternatywę dla Unii Europejskiej, uważanej z jednej strony za twór słabnący gospodarczo, z drugiej zaś za ekspansywną i agresywną organizację, dążącą do wchłonięcia Polski i wykorzystania jej potencjału dla podtrzymania rozwoju państw zachodnich, zwłaszcza Francji, Niemiec i Wielkiej Brytanii. W przeciwieństwie do UE, Stany Zjednoczone miały być zainteresowane jedynie rozwojem obustronnej współpracy, przynoszącej korzyści jednej i drugiej stronie?. R. Giertych powiedział: „Bli-

s. 13; Stworzyć Polsce alternatywę wobec wejścia do Unii Europejskiej, rozmowa z R. Giertychem, Nowa Myśl Polska (NMP), 30 VI 2002, nr 26, s. 7; Polityka suwerennego narodu, rozmowa z M. Giertychem, NMP, 11 VIII 2002, nr 32, s. 4; R. Giertych, To, co obiecaliśmy..., s. 5; wystąpienie R. Giertycha, IV kad., pos. 6 Sejmu z 29 XI 2001, Sejm RP, http://orka2.sejm.gov.pl/Debata4. nsf; wystąpienie R. Giertycha, IV kad., pos. 27 Sejmu z 24 VII 2002, Sejm RP, http://orka2.sejm. gov.pl/Debata4.nsf; wystąpienie M. Giertycha, IV kad., pos. 52 Sejmu z 8 VII 2003, Sejm RP, http://orka2.sejm.gov.pl/Debata4.nsf ; wystąpienie J. Dobrosza, IV kad., pos. 67 Sejmu...; wystąpienie M. Giertycha, IV kad., pos. 73 Sejmu z 14 IV 2004, Sejm RP, http://orka2.sejm.gov.pl/ Debata4.nsf; wystąpienie J. Dobrosza, IV kad., pos. 96 Sejmu...; M. Giertych, Stosunki europejsko-amerykańskie, październik 2006, nr 59, Opoka w Kraju (OwK), http://opoka.giertych.pl/owk59. htm [odczyt 1-4 i 10 II 2011].

6 Wystąpienie J. Dobrosza, IV kad., pos. 96 Sejmu...; M. Giertych, Stosunki....

7 Stworzyć Polsce alternatywę.., s. 7; Jestem przeciwnikiem rewolucji, rozmowa z R. Gierty- 
ska jest nam współpraca ze Stanami Zjednoczonymi w polityce gospodarczej”, ponieważ „związanie się ze Stanami Zjednoczonymi jest przyszłością dla polskiej gospodarki"'.

Jako trzeci powód współpracy z USA Liga przytaczała wzrost pozycji państwa polskiego w środowisku międzynarodowym, zwłaszcza wobec Unii Europejskiej. Jej przywódcy wychodzili z założenia, że skoro Stany Zjednoczone są światowym mocarstwem, więc status ich sojusznika i strategicznego partnera, jaki powinna osiągnąć Polska, zmusiłby wiele innych państw do większego niż dotychczas liczenia się z jej interesami. Uważali, że zacofanie ekonomiczne polskiego społeczeństwa, wynikające z trwającego pół wieku braku suwerenności państwowej i niemożności rozwoju cywilizacyjnego, zmuszało rządzących do integracji z UE, gdyż wyobrażali sobie, że dzięki temu nastąpi wyrównanie potencjału gospodarczego Polski z najbogatszymi krajami Starego Kontynentu. LPR obawiała się jednak akcesji do Unii, twierdząc, że udział w europejskiej organizacji ponadnarodowej pozbawi Rzeczpospolitą wielu atrybutów jej suwerenności i uzależni od władz w Brukseli a zwłaszcza głównych decydentów unijnych: Niemiec i Francji. Państwa te, w zamian za udzielenie zgody na pomoc gospodarczą i technologiczną Unii dla Polski miały narzucać władzom Rzeczypospolitej swoje żądania i zmuszać je do ich wykonywania, nawet jeśli byłoby to sprzeczne z interesem polskiego społeczeństwa. Dlatego oparte na partnerstwie stosunki ze Stanami Zjednoczonymi miały być alternatywą dla jakichkolwiek antypolskich działań unijnych oraz zapewnić państwu polskiemu odpowiednie wsparcie materialne i możliwości rozwoju bez utraty przez nie podmiotowości prawnomiędzynarodowej. Przywódcy LPR uważali, że wówczas przed Polską stanęłyby dwie atrakcyjne możliwości wyboru. Po pierwsze, niezależność od nieprzyjaznych działań ze strony głównych państw unijnych, ponieważ państwo polskie nic by od nich nie potrzebowało, więc nie musiałoby poddawać się ich dyktatowi. Po drugie, zwiększałoby siłę przetargową władz polskich w momencie negocjacji z UE, gdyby jednak zdecydowano się włączyć w jej struktury. Jednak wówczas Polska, jako sojusznik Stanów Zjednoczonych, chroniona przez nie politycznie i militarnie oraz rozwijająca się ekonomicznie dzięki amerykańskiej pomocy, stałaby się jednym z wiodących państw na kontynencie europejskim?. R. Giertych powiedział: „Alternatywą dla Polski jest

chem, NMP, 6 VI 2004, nr 23, s. 4; wystąpienie R. Giertycha, IV kad., pos. 6 Sejmu...; wystąpienie R. Giertycha, IV kad., pos. 27 Sejmu...; wystąpienie M. Giertycha, IV kad., pos. 73 Sejmu...

8 Stworzyć Polsce alternatywę..., s. 7; wystąpienie R. Giertycha, IV kad., pos. 27 Sejmu...

9 J. M. Jackowski, PAX..., s. 13; Polityka suwerennego..., s. 4; wystąpienie R. Giertycha, IV kad., pos. 6 Sejmu...; wystąpienie R. Giertycha, IV kad., pos. 27 Sejmu...; wystąpienie M. Giertycha, IV kad., pos. 52 Sejmu...; wystąpienie M. Giertycha, IV kad., pos. 73 Sejmu...; Relacje z USA 
suwerenność” i „Związanie gospodarki bardziej ze Stanami Zjednoczonymi”. Natomiast zdaniem Anny Raźny, przewodniczącej Rady Politycznej (2008-2010), celem sojuszu z USA jest „Zachować suwerenność i zbudować silne państwo narodowe"10.

Jednak Liga stała na stanowisku, że nie tylko Polska odniosłaby korzyści ze współpracy ze Stanami Zjednoczonymi. Zdaniem liderów ugrupowania również i USA korzystały za bliskich relacjach z państwem polskim, przede wszystkim pod względem prestiżowym i politycznym. Głównym powodem takiego rozumowania było przekonanie o tym, że mocarstwo amerykańskie poszukuje sojuszników w każdej części świata. W Europie jedynym wiernym sprzymierzeńcem USA była Wielka Brytania, dlatego też przywódcy LPR starali się przekonać opinię publiczną, że Polska powinna pełnić rolę drugiego lojalnego sojusznika i partnera Stanów Zjednoczonych na kontynencie. Twierdzili, że bez współdziałania z Polską Amerykanie nie mogliby skutecznie działać w regionie Europy środkowo-wschodniej i nie mieliby oparcia dla swojej polityki względem państw dawnego Związku Radzieckiego. Swoje stanowisko opierali m.in. o skutki wojny w Iraku 2003 roku, w wyniku której doszło do napięcia między Stanami Zjednoczonymi a przywódcami unijnymi - Niemcami i Francją. Sytuacja ta, jak twierdzono, miała być czynnikiem ułatwiającym Polsce zacieśnienie stosunków z USA oraz wzmocnienie tym samym swojej pozycji w Europie. Przywódcy LPR sądzili, że im bardziej USA i Unia Europejska pozostawałyby ze sobą w konflikcie, tym mocniej Amerykanie szukaliby sojuszników na Starym Kontynencie, oferując im różne profity w zamian za wsparcie polityczne a jedynymi państwami, które zawsze deklarowały poparcie dla Stanów Zjednoczonych w Europie były Wielka Brytania i Polska. Stąd też uważano, że Polska powinna wykorzystać tę okazję, aby wykazać swoją niezbędność dla europejskiej polityki Stanów Zjednoczonych, zaś USA odpowiednio ją za to wynagrodzić, jeśliby nie chciały utracić jednego z wiernych sojuszników na kontynencie. Gdyby tak się stało, to amerykańskie państwo zostałoby wypchnięte z Europy, tracąc wpływy, oparcie a tym samym swoją pozycję hegemona, co, jak przekonywano, nie było do zaakceptowania dla władz w Waszyngtonie ${ }^{11}$. R. Giertych powiedział: „W najlepszym interesie Stanów Zjednoczonych jest to, aby poprzeć Polskę niepodległą”. Natomiast zdaniem M. Giertycha: „Dla USA Polska musi być cennym partnerem"12.

trzeba zrównoważyć, rozmowa z A. Raźny, Nasz Dziennik (ND), 17-18 XI 2007, nr 269, s. 19; M. Giertych, Stosunki....

10 Wystąpienie R. Giertycha, IV kad., pos. 27 Sejmu...; Relacje z USA..., s. 19.

11 J. M. Jackowski, PAX..., s. 13; Stworzyć Polsce alternatywę.., s. 7; Polityka suwerennego..., s. 4.

12 Stworzyć Polsce alternatywę.., s. 7; Polityka suwerennego..., s. 4. 
Mimo zapewnień o potrzebie lojalności i bliskim sojuszu Polski ze Stanami Zjednoczonymi przywódcy LPR sprzeciwiali się jednak bezwarunkowemu i bezwzględnemu popieraniu amerykańskiej polityki. Uważając za konieczne zacieśnianie współpracy polsko-amerykańskiej, twierdzili jednocześnie, że ta współpraca powinna opierać się na partnerstwie i wzajemnym poszanowaniu obu państw. Uważali, że Polska powinna wspierać Stany Zjednoczone w ich polityce światowej czy europejskiej, ale tylko w tym przypadku jeśli cele ich polityki są zgodne z prawem międzynarodowym, moralnością lub wynikają z umów dwustronnych i wielostronnych, których państwo polskie było sygnatariuszem. Liderzy Ligi żądali jednak, aby USA, w zamian za lojalność i wsparcie, uwzględniały w swoich zamierzeniach również interesy państwowe i narodowe Rzeczypospolitej. Ich zdaniem prawdziwa suwerenność polegała bowiem na tym, że Polska musiała prowadzić politykę niezależną od nikogo i kierować się przede wszystkim własnymi korzyściami a nie pod pozorem rzekomego sojuszu dawać się wykorzystywać innym państwom. Dlatego też stali na stanowisku, że żaden układ międzynarodowy podpisany przez państwo polskie nie może stać się instrumentem działania wbrew polskim interesom. W stosunku do Stanów Zjednoczonych oznaczało to, że Polska musi tak ułożyć swoje relacje z tym mocarstwem, aby służyły one realizacji jej strategicznych celów i zamierzeń a jeśli już wspierałaby USA w działaniach nieprzynoszących jej bezpośrednich korzyści, wówczas powinna żądać w zamian rekompensaty politycznej, ekonomicznej lub militarnej. Wśród najczęściej powtarzanych postulatów wymieniano: zniesienie wiz dla polskich obywateli udających się do Stanów Zjednoczonych, przekazanie w ramach offsetu polskim przedsiębiorstwom różnych technologii, przekazanie środków finansowych i materialnych na unowocześnienie polskiej armii, powstrzymanie roszczeń środowisk żydowskich wobec Polski, utrzymanie klauzuli najwyższego uprzywilejowania w handlu oraz poparcie polskiej polityki wobec niemieckiego rewizjonizmu i dążeń Rosji do wciągnięcia Polski w swoją strefę wpływów. W przypadku odmowy realizacji przez Stany Zjednoczone tych i innych ważnych dla państwa polskiego warunków LPR żądała ograniczenie przez polskie władze angażowania się we wspieranie amerykańskich inicjatyw, uważając, że w polityce musi istnieć zasada wzajemności, będąca podstawą partnerskich stosunków międzynarodowych ${ }^{13}$. R. Giertych,

13 Nie jesteśmy chtopcem..., s. 26; Jestem przeciwnikiem..., s. 4; R. Giertych, Polska zastuguje na więcej!, NMP, listopad 2004, s. 13; wystąpienie R. Giertycha, IV kad., pos. 43 Komisji Łączności z Polakami za Granicą KŁPG) z 20 I 2004, Sejm RP, http://orka.sejm.gov.pl/SQL.nsf/Main4?OpenForm\&LPG; wystąpienie J. Dobrosza, V kad., pos. 10 Sejmu z 15 II 2006, Sejm RP, http://orka2.sejm.gov.pl/Debata5.nsf [odczyt 6-8 II 2011]; M. Giertych, Stosunki...; Trzeba powstrzymać degradację Polski i Europy, rozmowa z A. Raźny, ND, 21 IX 2005, nr 221, s. 10; Relacje zUSA..., s. 19. 
odnosząc się do USA, powiedział: „W relacjach z mocarstwami (...) będziemy prezentowali zasadę twardej obrony interesów”. Natomiast M. Giertych napisał: „Za popieranie Ameryki (...) trzeba żądać poważnego wsparcia”14.

Optymistyczne plany polskiej polityki względem Stanów Zjednoczonych, jakie próbowali nakreślić przywódcy LPR, okazały się jedynie niezrealizowanymi marzeniami, ponieważ w rzeczywistości USA nie realizowały niemal nic z powyżej nakreślonych postulatów. Władze amerykańskie nie zniosły wiz dla polskich obywateli, co z czasem stało się miernikiem stosunku Stanów Zjednoczonych do Polski, nie udzieliły wsparcia finansowego dla modernizacji polskiej armii zaś kwestia offsetu związanego z zakupem amerykańskich samolotów wielozadaniowych F-16 przyniosła jedynie minimalne korzyści, gdyż Amerykanie przez dłuższy czas zwlekali z transferem technologii zbrojeniowej ${ }^{15}$. W LPR zauważono tę politykę i komentowano ją na forum sejmowym i medialnym, krytykując postawę administracji George’a W. Busha. Uważano, że władze amerykańskie wykorzystywały państwo polskie do swoich interesów, jako przykład podając udział wojsk polskich w operacjach militarnych w Afganistanie i Iraku oraz próby zainstalowania tarczy antyrakietowej w Polsce. Nie liczyły się przy tym z interesami Rzeczypospolitej. Wszelkie słowa na temat przyjaźni i partnerstwa, jakie amerykański prezydent i czołowi politycy USA wypowiadali odnośnie stosunków amerykańsko-polskich, przywódcy LPR z czasem zaczęli traktować jako kłamstwa, mające na celu zmylić rządzących Polską co do prawdziwych intencji Stanów Zjednoczonych, by utrzymać ją w sferze swoich wpływów. W Lidze uważano, że jeśli te słowa byłyby szczere, wówczas miałyby pokrycie w propolskich działaniach USA, zmierzających do uwzględnienia w swojej polityce interesów Rzeczypospolitej. Tymczasem jednak, jak twierdzono, Stany Zjednoczone zwasalizowały Polskę, natomiast polscy rządzący, w imię dobrych stosunków polsko-amerykańskich gotowi byli wypełnić każde polecenie władz z Waszyngtonu ${ }^{16}$. Dobrosz w 2004 roku powiedział: „Naród polski czuje się obecnie upokarzany przez Amerykę”. Natomiast Sylwester Chruszcz, wiceprezes Zarządu Głównego (2001-2007) i p.o. prezesa (2007-2008) stwierdził: „Nasz amerykański sojusznik, (...) który wielokrotnie mógł liczyć na

14 R. Giertych, Polska zastuguje..., s. 5; M. Giertych, Stosunki...

15 A. Dudek, Historia polityczna Polski 1989-2005, Kraków 2007, s. 428-429.

16 Dlaczego mamy się bić o Irak?, rozmowa z R. Giertychem, RP, maj 2004, s. 2; S. Chruszcz, ZSRS lepszy niż USA? O tarczy i wizach, 23 V 2008, blog S. Chruszcza, http://chruszcz.blog.onet. pl/2008/05/23/zsrs-lepszy-niz-usa-o-tarczy-i-wizach; wystąpienie J. Dobrosza, IV kad., pos. 67 Sejmu...; wystąpienie Z. Wrzodaka, IV kad., pos. 86 Sejmu z 13 X 2004, Sejm RP, http://orka2. sejm.gov.pl/Debata4.nsf; wystąpienie Z. Wrzodaka, IV kad., pos. 106 Komisji Gospodarki (KG) i pos. 57 KON z 13 III 2003, Sejm RP, http://orka.sejm.gov.pl/SQL.nsf/Main4?OpenForm\&GOS; wystąpienie R. Giertycha, IV kad., pos. 43 KŁPG... [odczyt 4, 8 i 10 II 2011]. 
nasze wsparcie (...) traktuje Polaków gorzej niż Niemców, Francuzów, Czechów czy Irlandczyków" ${ }^{17}$. Niemniej jednak nadal przywódcy LPR byli przekonani, że Stany Zjednoczone były lepszą alternatywą dla Polski niż Unia Europejska i uważali, że trzeba wszystko robić, aby zmienić nastawienie Amerykanów do państwa polskiego. Świadczy o tym wypowiedź Dobrosza, który wprawdzie stwierdził, że „doszło do wasalnych stosunków między Stanami Zjednoczonymi a Polską”, jednak dodawał: „To nie znaczy, że my nie powinniśmy na arenie międzynarodowej robić wszystkiego, aby wspierać Stany Zjednoczone"18.

\section{Kwestia wojny w Iraku}

Liga Polskich Rodzin za jeden z priorytetów polskiej polityki zagranicznej uważała zacieśnianie stosunków ze Stanami Zjednoczonymi, jednak sprzeciwiała się, aby bezwarunkowo i bezrefleksyjnie popierać działania amerykańskiego mocarstwa. Do działań, którym państwo polskie powinno się przeciwstawiać lub chociażby zachowywać wobec nich neutralność zaliczano wojnę w Iraku. Przywódcy Ligi zdawali sobie sprawę, że Polska jest za słaba, aby wpłynąć na politykę USA odnośnie Bliskiego Wschodu, ale uważali, że powinna ona w tej sprawie kierować się własnym interesem, za który uważali zachowanie neutralności i niemieszanie się w sprawy państw muzułmańskich. Swoje negatywne stanowisko odnośnie decyzji prezydenta i rządu o wysłaniu polskich żołnierzy do Iraku w celu wsparcia wojsk amerykańskich uzasadniali kilkoma powodami: 1) zanegowaniem powodów, dla których Stany Zjednoczone zaatakowały Irak, 2) przedstawieniem prawdziwych celów wojny, 3) wykazaniem sprzeczności wojny z prawem międzynarodowym a udziału wojsk polskich z konstytucją Rzeczypospolitej, 4) przedstawieniem zagrożeń, jakie niosło dla Polski zaangażowanie militarne w tym regionie oraz 5) brakiem interesów państwa polskiego w popieraniu konfliktu bliskowschodniego $^{19}$. Zygmunt Wrzodak powiedział: „Ta wojna nie jest wojną naszego państwa i naszego narodu”. Podobnie stwierdził Wojciech Wierzejski, skarbnik (2001-2006) i wiceprezes Zarządu Głównego (2006-2007): „To nie nasza wojna”20.

17 Wystąpienie J. Dobrosza, IV kad., pos. 67 Sejmu...; S. Chruszcz, ZSRS....

18 Wystąpienie J. Dobrosza, V kad., pos. 41 Sejmu....

19 W. Wierzejski, Nie unikna debaty, RP, 30 III 2003, nr 5, s. 3; Wojna bez moralnego usprawiedliwienia, rozmowa z M. Giertychem, RP, 30 III 2003, nr 5, s. 5-6; Dlaczego mamy się bić..., s. 2; wystąpienie Z. Wrzodaka, IV kad., pos. 44 Sejmu z 26 III 2003, Sejm RP, http://orka2. sejm.gov.pl/Debata4.nsf; wystąpienie J. Dobrosza, IV kad., pos. 96 Sejmu... [odczyt 3 II 2011]; M. Giertych, Stosunki....

20 Wystąpienie Z. Wrzodaka, IV kad., pos. 44 Sejmu...; W. Wierzejski, Nie unikną..., s. 3. 
LPR stała na stanowisku, że powody, dla których Stany Zjednoczone zaatakowały Irak w marcu 2003 roku, były powodami fałszywymi lub miały na celu ukrycie faktycznych celów amerykańskiej polityki na Bliskim Wschodzie. Wśród fałszywych przyczyn wymieniano oskarżanie reżimu Husajna o sprzyjanie terrorystom oraz posiadanie broni masowej zagłady. Przywódcy LPR twierdzili, że nikt nie udowodnił powiązań między iracką władzą a Al-Kaidą, ugrupowaniem terrorystycznym, które zaatakowało we wrześniu 2001 roku Waszyngton i Nowy Jork ani tym bardziej o sprzyjanie mu przez Husajna lub osoby z jego otoczenia. Nie udało się Amerykanom również wykazać, że organizacja ta miała jedną z siedzib na terenie Iraku. Liderzy Ligi twierdzili coś przeciwnego - uważali, że Saddam Husajn i jego świeckie rządy były wrogami fundamentalizmu islamskiego i różnych terrorystycznych organizacji muzułmańskich, dlatego też Al-Kaida byłaby zwalczana na terenie państwa irackiego. Dlatego oskarżenia amerykańskie uznawano za świadome wprowadzenie opinii publicznej w błąd. Jako fałszerstwo uważano również posądzenia Irakijczyków o posiadanie broni masowego rażenia. LPR, powołując się na badania komisji międzynarodowej, wychodziła z założenia, że skoro inspektorzy ONZ nie stwierdzili istnienia takiej broni na terytorium państwa irackiego, więc przytaczanie przez władze amerykańskie tego argumentu jako powodu ataku także było celową dezinformacją. Dwa kolejne powody - wprowadzenie demokracji i obrona Kurdów przed prześladowaniami - zostały natomiast potraktowane jako cele pozorne, mające nadać amerykańskiemu atakowi pozory moralności. Liderzy Ligi uważali, że narzucanie siłą demokratycznego porządku innym państwom jest sprzeczne z prawem narodów do samostanowienia o swoim losie, więc sprzeciwiali się takiemu uzasadnianiu ingerencji w Iraku. Jako argument za swoim stanowiskiem przytaczali również fakt, że społeczeństwa arabskie nie są wychowane w kulturze demokratycznej, więc jakakolwiek zmiana systemu politycznego może spowodować destabilizację wewnętrzną państwa. Narzucanie demokracji w Iraku przez USA uważano również za działanie obłudne, twierdząc, że Amerykanie powinni na całym świecie angażować się w obalanie systemów niedemokratycznych, w tym u swoich sojuszników - Turcji i Arabii Saudyjskiej - a skoro tego nie robią, więc nie powinni czynić tego w Iraku. Ostatni argument, czyli obrona narodu kurdyjskiego przed prześladowaniami, również został zanegowany. LPR stała na stanowisku, że Kurdowie byli prześladowani nie tylko w Iraku, ale także w innych państwach, więc jeśli celem byłaby ich obrona, to Amerykanie powinni zaangażować się w budowanie niepodległego Kurdystanu i wyzwolenie tego narodu spod panowania zarówno Iraku, jak i Turcji oraz Iranu ${ }^{21}$. Wrzodak powiedział: „Oszuka-

${ }^{21}$ Wojna bez moralnego..., s. 5-6; Dlaczego mamy się bić..., s. 2; wystąpienie Z. Wrzodaka, 
na została opinia publiczna”. Natomiast Maciej Giertych napisał: „Nie uważaliśmy tej wojny za moralnie uzasadnioną"22.

Negatywne stanowisko LPR odnośnie konfliktu w Iraku i polskiego w nim zaangażowania wynikało również z prezentowania prawdziwych, z punktu widzenia jej przywódców, powodów wojny. Do nich zaliczano chęć Stanów Zjednoczonych do zdobycia terenów bogatych w ropę naftową, znajdujących się na terytorium irackim. Uważano, że Amerykanie zamierzali podbić Irak, ustanowić kontrolowany przez siebie rząd a następnie eksploatować na własne potrzeby istniejące tam surowce. LPR stała na stanowisku, że ten konflikt był wojną kolonialną wywołaną egoistycznymi celami amerykańskiego mocarstwa, zmierzającego do rozwoju swojej potęgi, który nie miał nic wspólnego z deklarowanymi oficjalnie przyczynami ataku. Natomiast oficjalne stanowisko władz USA miało na celu pozyskać sprzymierzeńców, którzy za pomocą wsparcia militarnego i politycznego ułatwiliby realizację amerykańskich zamierzeń. Drugą przyczyną wojny miały być interesy Izraela, sojusznika Stanów Zjednoczonych na Bliskim Wschodzie. Przywódcy Ligi twierdzili, że Izraelczycy toczą wojnę z sąsiadującymi krajami arabskimi, wspieranymi przez inne państwa muzułmańskie. Celem Izraela było więc, według liderów LPR, wywołanie wielkiego konfliktu, który miał zadecydować o jego panowaniu w regionie między Zatoką Perską a Morzem Śródziemnym, a pierwszym etapem ku temu miało być podbicie Iraku. Dlatego władze izraelskie, za pośrednictwem USA, poszukiwały sojuszników, którzy wsparliby je w realizacji tego celu. Oba powody wojny irackiej nie stały, zdaniem przywódców LPR, w sprzeczności. Uważali bowiem, że skoro celem Amerykanów była eksploatacja złóż irackiej ropy naftowej, to temu zamierzeniu ułatwiłaby likwidacja zagrożenia muzułmańskiego i opanowania regionu przez sojusznicze państwo izraelskie, w którym Amerykanie mieliby duże wpływy. Dlatego też LPR sprzeciwiała się zaangażowaniu Rzeczypospolitej w ten konflikt i wykorzystywania jej potencjału gospodarczego i militarnego dla realizacji ekspansywnych i zaborczych interesów amerykańskich i izraelskich. Swoje stanowisko uzasadniała tym, że Polacy w swej historii nigdy nie brali udziału w wojnach kolonialnych a także nie byli okupanta-

IV kad., pos. 44 Sejmu...; wystąpienie Z. Wrzodaka, IV kad., pos. 62 Sejmu z 28 XI 2003, Sejm RP, http://orka2.sejm.gov.pl/Debata4.nsf; wystąpienie M. Giertycha, IV kad., pos. 173 KG, pos. $100 \mathrm{KON}$ i pos. 144 Komisji Spraw Zagranicznych (KSZ) z 6 I 2004, Sejm RP, http://orka.sejm. gov.pl/SQL.nsf/Main4?OpenForm\&GOS; wystąpienie Z. Wrzodaka, IV kad., pos. $120 \mathrm{KON}$ i pos. $177 \mathrm{KSZ}$ z $13 \mathrm{~V}$ 2004, Sejm RP, http://orka.sejm.gov.pl/SQL.nsf/Main4?OpenForm\&SZA; wystąpienie J. Dobrosza, V kad., pos. $10 \mathrm{KON}$ i pos. $27 \mathrm{KSZ}$ z 22 III 2006, Sejm RP, http://orka. sejm.gov.pl/SQL.nsf/Main5?OpenForm\&OBN; M. Giertych, Polska w Iraku, lipiec 2003, nr 45, OwK, http://opoka.giertych.pl/owk45.htm [odczyt 3 i 8-10 II 2011].

22 Wystąpienie Z. Wrzodaka, IV kad., pos. 120 KON...; M. Giertych, Polska.... 
mi żadnego terytorium, więc i tym razem nie powinni brać udziału w konflikcie irackim, tym bardziej w sytuacji, kiedy Polska nie miała w nim żadnego interesu ${ }^{23}$. M. Giertych powiedział: „Poza oczywistymi interesami finansowymi, związanymi z ropą naftową - ta wojna jest przede wszystkim przedłużeniem konfliktu izraelsko-palestyńskiego”, więc „Polska nie powinna być stroną w tym konflikcie”. Natomiast Wierzejski napisał: „Jestem przeciw wysyłaniu polskich wojsk na amerykańskie ekspedycje" ${ }^{24}$.

Kolejnym argumentem, przemawiającym, według LPR, za nieangażowaniem się Polski w konflikt iracki był brak zgody ONZ na amerykański atak. Przywódcy Ligi twierdzili, że żadna rezolucja Rady Bezpieczeństwa nie upoważniała Stanów Zjednoczonych do użycia sił zbrojnych przeciw Irakowi, więc naruszyły one prawo wszczynając wojnę wbrew stanowisku społeczności międzynarodowej. Oznaczało to, zdaniem liderów partii, że również Polska, popierając czynnie zbrojną interwencję sama stawała się państwem łamiącym normy międzynarodowe. O złamanie prawa, tym razem krajowego, oskarżono również prezydenta Kwaśniewskiego i premiera Millera, którzy podjęli decyzję o wysłaniu polskich żołnierzy do Iraku bez zgody Sejmu i bez obiektywnych warunków, uzasadniających tę decyzję. LPR stała na stanowisku, że udział polskich żołnierzy w operacji „Iracka Wolność”, nawet bez formalnego wypowiedzenia wojny, uczynił z państwa polskiego stronę konfliktu. Powołując się na artykuł 116 konstytucji przywódcy ugrupowania twierdzili, że o wypowiedzeniu wojny decyduje Sejm i to w wyniku bezpośredniej agresji wroga na terytorium Rzeczypospolitej lub jej sojuszników. Tymczasem taka sytuacja nie zaistniała, bo USA nie zostały zaatakowane przez Irak, więc polskie władze nie miały obowiązku a nawet prawa angażować polskich sił zbrojnych w wojnę po stronie Stanów Zjednoczonych. Wysłanie Polskiego Kontyngentu Wojskowego odbyło się więc, jak liderzy LPR przekonywali opinię publiczną, z naruszeniem norm prawa międzynarodowego, zakazującego wojny napastniczej (nawet jeśli by to była wojna prewencyjna) oraz polskiej konstytucji ${ }^{25}$. Roman

${ }^{23}$ Wojna bez moralnego..., s. 5-6; Nie jesteśmy chtopcem..., s. 26; R. Giertych, Polska zastuguje..., s. 13; Nasza rola nie jest zmienianie władzy w innych krajach, rozmowa z M. Giertychem, MP, 4 IX 2005, nr 36, s. 4; wystąpienie M. Giertycha, IV kad., pos. 40 Sejmu...; wystąpienie Z. Wrzodaka, IV kad., pos. 62 Sejmu...; wystąpienie M. Giertycha, IV kad., pos. 173 KG...; wystąpienie Z. Wrzodaka, IV kad., pos. 65 KON...; wystąpienie Z. Wrzodaka, IV kad., pos. 120 KON...; M. Giertych, Polska....

24 Wojna bez moralnego..., s. 6; W. Wierzejski, Wystawa o cywilnych ofiarach wojny w Iraku, 23 X 2006, blog W. Wierzejskiego (SI Wierzejski), http://wierzejski.blog.onet.pl/2006/10/23/wystawa-o-cywilnych-ofiarach-wojny-w-iraku [odczyt 10 II 2011].

25 Wojna bez moralnego..., s. 5-6; Dlaczego mamy się bić..., s. 2; Polska powinna zachować neutralność, NMP, 6 IV 2003, nr 14, s. 3; W. Wierzejski, Wystawa...; wystąpienie Z. Wrzodaka, IV 
Giertych odnośnie wojny powiedział: „Naruszono normy prawa międzynarodowego przy wysyłaniu wojsk” przez co „zostaliśmy wciągnięci w sytuację, która tak naprawdę nie jest do końca naszą sytuacją". Wrzodak wypowiedział się podobnie: „Włączenie się Polski w agresję na Irak i wysłanie polskich wojsk (...) było niezgodne z prawem międzynarodowym”, a ponadto „ci, którzy rozstrzygnęli o wysłaniu polskiego wojska do Iraku złamali konstytucję"26.

O ile powyższe przyczyny niechęci LPR do wojny miały charakter moralny, wynikający z określonych wartości, o tyle dwie kolejne dotyczyły skutków, jakich Polska mogła doświadczyć lub doświadczyła angażując się w iracki konflikt. Pierwszy z argumentów związany był z obawami o bezpieczeństwo państwa i społeczeństwa polskiego. Przywódcy partii uważali, że militarne zaangażowanie Rzeczypospolitej w amerykański atak na Irak i powojenną jego okupację narażało obywateli i struktury państwa na groźbę odwetu ze strony muzułmanów. Jako przykład podawano polskich żołnierzy, którzy przebywając w swojej strefie okupacyjnej byli ciągle narażeni na ataki ze strony irackich zwolenników Husajna oraz islamskich fundamentalistów. Śmierć lub rany któregoś z członków PKW tylko umacniały przekonanie LPR o błędzie, jakim było wysłanie polskich sił zbrojnych nad Zatokę Perską. Obawiano się również, że udział polskich żołnierzy po stronie Stanów Zjednoczonych uczyni z Polski jednego z głównych wrogów świata arabskiego i muzułmańskiego. Takie postrzeganie państwa polskiego mogło okazać się katastrofalne w skutkach dla społeczeństwa w kraju, gdyż nie wykluczano sytuacji, w której bojownicy z Iraku lub innych wspierających ich państw muzułmańskich przeprowadziliby atak na terytorium Rzeczypospolitej. Przykładem odwetu ze strony islamskich fundamentalistów wobec państwa zaangażowanego w konflikt iracki był atak w Madrycie w marcu 2004 roku, w wyniku którego śmierć poniosło około 200 osób. Liderzy LPR powoływali się na to wydarzenie jako coś, co mogło spotkać Polskę, jeśli nadal angażowałaby się w okupację Iraku. Niebagatelną sprawą był również fakt, narażenia na niebezpieczeństwo wszystkich polskich obywateli przebywających na Bliskim Wschodzie. Twierdzono, że jeśli, jak przypuszczano, rozpocznie się wielka wojna Izraela i Stanów Zjednoczonych przeciw państwom muzułmańskim, wówczas Polska, stojąc po stronie izraelsko-amerykańskiej zostanie narażona na ataki na swoje placówki dyplomatyczne oraz różnego rodzaju organizacje i instytucje społeczne, gospodarcze i kulturalne, mieszczące się w tym regionie. Sytuację tą uważano za tym groźniejszą,

kad., pos. 44 Sejmu...; wystąpienie Z. Wrzodaka, IV kad., pos. 62 Sejmu...; wystąpienie J. Dobrosza, IV kad., pos. 67 Sejmu....

${ }^{26}$ Dlaczego mamy się bić..., s. 2; wystąpienie Z. Wrzodaka, IV kad., pos. 62 Sejmu.... 
ponieważ, jak sądzono, państwo polskie nie miało odpowiednich sił, aby zadbać o interesy swoich obywateli na Bliskim Wschodzie i ochronić ich przed atakami terrorystycznymi i działaniami militarnymi ze strony wroga. W razie natomiast większego zaangażowania sił zbrojnych po stronie USA i Izraela doszłoby do podzielenia i tak nielicznej polskiej armii i wysłanie ich części nad Zatokę Perską, co osłabiłoby potencjał obronny Rzeczypospolitej w razie ewentualnego ataku zbrojnego ze strony muzułmanów ${ }^{27}$. Wrzodak powiedział: „Prezydent i rząd stanęli po stronie wojny i tym samym narazili nasze państwo na akty odwetu". Natomiast zdaniem Janusza Dobrosza: „Dalszy udział Polski w misji stabilizacyjnej w Iraku do niczego nie prowadzi i może eskalować niepokoje" ${ }^{28}$.

Wczytując się w wypowiedzi przywódców LPR można dojść do wniosku, że powyższe przyczyny niechętnej postawy wobec wojny można byłoby ominąć, gdyby nie ostatnia z nich $\mathrm{i}$, jak się wydaje, najważniejsza według hierarchii wartości. Przyczyną tą był brak korzyści, wynikających z zaangażowania Polski w konflikt iracki. Liderzy ugrupowania oskarżali polskie władze, że, wysyłając żołnierzy na Bliski Wschód, nie zażądały od Stanów Zjednoczonych gwarancji politycznych i gospodarczych, jakie powinny uzyskać w zamian za wsparcie USA w tym konflikcie. Wśród tych korzyści wymieniano m.in. zniesienie wiz dla obywateli polskich chcących wjechać na terytorium amerykańskie oraz uzyskanie większego wsparcia finansowego i materialnego dla potrzeb polskiej gospodarki i armii. Oprócz tego Polska liczyła na zyski związane z odbudową i modernizacją Iraku. Wielu polityków i rządzących przekonywało, że w zamian za poparcie interwencji zbrojnej polskie przedsiębiorstwa uzyskają odpowiednie kontrakty na dostawy do Iraku żywności, maszyn rolniczych i budowlanych oraz sprzętu wojennego a także będą mogły inwestować i tworzyć swoje filie zagraniczne w tym kraju, uczestniczące w naprawie infrastruktury drogowej, przemysłowej i komunalnej. Dzięki temu wzbudzono w społeczeństwie nadzieję na rozwój polskiej gospodarki i powstawanie tysięcy nowych miejsc pracy, potrzebnych do realizacji irackich kontraktów ${ }^{29}$. Tymczasem, opierając się na informacjach ministerstw i firm przemysłowych, przywódcy LPR przekonywali, że większość tych postulatów nie zo-

27 Dlaczego mamy się bić..., s. 2; Polska powinna zachować..., s. 3; W. Wierzejski, $O$ „tarczy" $i$ otwartych funduszach emerytalnych, 22 I 2007, SI Wierzejski, http://wierzejski.blog.onet. pl/2007/01/22/o-tarczy-i-otwartych-funduszach-emerytalnych; wystąpienie Z. Wrzodaka, IV kad., pos. 44 Sejmu...; wystąpienie Z. Wrzodaka, IV kad., pos. 65 KON...; wystąpienie Z. Wrzodaka, IV kad., pos. $120 \mathrm{KON}$... [odczyt 10 II 2011].

28 Wystąpienie Z. Wrzodaka, IV kad., pos. 44 Sejmu...; wystąpienie J. Dobrosza, V kad., pos. $10 \mathrm{KON} . .$.

29 M. Wągrowska, Udziat Polski...; D. Materniak, J. Rutkowska, M. P. Żukowska, Irak... 
stała zrealizowana a polskie przedsiębiorstwa w Iraku, zamiast zyskownych umów i inwestycji mogły liczyć w najlepszym wypadku na podwykonawstwo i to w nielicznych dziedzinach Oznaczało to upadek nadziei na uzyskanie większych korzyści z wojny, które mogły przyczynić się do wyjścia polskiej gospodarki z kryzysu. Liga stała na stanowisku, że Polska nie tylko nie uzyskała spodziewanych zysków, ale jeszcze musiała dopłacać do swojego udziału w irackiej okupacji. Podawano, że Amerykanie jedynie w części finansowali udział PKW, natomiast resztę kosztów pokrywano z budżetu państwa polskiego. Liderzy LPR wykazywali więc, jakim nieodpowiedzialnym posunięciem było utrzymywanie polskiego kontyngentu w Iraku, twierdząc, że udział w nieswojej wojnie, niosącej zagrożenia dla obywateli i państwa polskiego, w dodatku opłacany przez polskich podatników i bez spodziewanych korzyści był wbrew polskim interesom państwowym i narodowym ${ }^{30}$. Wrzodak powiedział o udziale Polski: „Jest to klęska na każdym polu - i polityczna (...), i gospodarcza”. Natomiast zdaniem Anny Raźny „udział w wojnach w Iraku i Afganistanie szkodzi Polsce”, ponieważ „nie uzyskaliśmy niczego. Ani pomocy materialnej, ani nawet deklaracji poparcia dla Polski w naszych fatalnych relacjach z Rosją"31.

Wymienione wyżej argumenty za neutralnością Polski w konflikcie irackim były podstawą do formułowania stanowiska LPR odnośnie tego problemu. Można wymienić trzy stanowiska, jakie ugrupowanie zajmowało. Po pierwsze, optowanie za niewysyłaniem polskich żołnierzy do Iraku a potem za jak najszybszym wycofaniem ich z tego kraju. Uważano, że im dłużej PKW pozostawać będzie nad Zatoką Perską, tym Polska narażona zostanie na większe niebezpieczeństwo odwetu ze strony muzułmanów. Po drugie, optowanie za wycofaniem polskich żołnierzy, traktowane jednak jako nacisk na Stany Zjednoczone, by spełniły polskie oczekiwania polityczne i ekonomiczne. Zgadzano się bowiem na udział polskiego kontyngentu w okupacji Iraku ale tylko pod warunkiem, że przyniesie on wymierne korzyści państwu i społeczeństwu polskiemu. Po trzecie, optowanie za poddaniem problemu irackiego decyzji ONZ. Uważano, że jedynie ta organizacja ma prawo podjąć decyzję odnośnie przyszłości Iraku i inne kraje powinny się jej podporządkować. LPR zgadzała się w tym wypadku na udział polskich żołnierzy jako części międzynarodowych sił pokojowych, twierdząc, że misja iracka pod

30 Dlaczego mamy się bić..., s. 2; Jestem przeciwnikiem..., s. 4; W. Wierzejski, O „tarczy”...; wystąpienie Z. Wrzodaka, IV kad., pos. 44 Sejmu...; wystąpienie Z. Wrzodaka, IV kad., pos. 62 Sejmu...; wystąpienie Z. Wrzodaka, IV kad., pos. 86 Sejmu...; wystąpienie Z. Wrzodaka, IV kad., pos. $173 \mathrm{KG}$.; wystąpienie Z. Wrzodaka, IV kad., pos. $65 \mathrm{KON}$...; wystąpienie Z. Wrzodaka, IV kad., pos. $120 \mathrm{KON}$...; Trzeba powstrzymać degradację..., s. 10.

31 Wystąpienie Z. Wrzodaka, IV kad., pos. 173 KG...; Trzeba powstrzymać degradacje..., s. 10. 
patronatem ONZ będzie faktycznie realizować cele pokojowe i stabilizacyjne a nie ekspansywne i kolonialne, jak w przypadku amerykańskiej okupacji. Te trzy cele wzajemnie się uzupełniały a Liga stała na stanowisku, że przyjęcie któregoś z nich przez Polskę zależeć powinno od sytuacji międzynarodowej. Niemniej jednak każdy z nich negował sytuację, w której polscy żołnierze mieliby wspierać czynnie Stany Zjednoczone w działaniach, przynoszących lub mogących przynieść Rzeczypospolitej straty moralne i materialne ${ }^{32}$. M. Giertych powiedział: „Trzeba, żebyśmy uczestniczyli w operacjach pokojowych ONZ czy innych (...) Również powinniśmy uczestniczyć w wojnach, które dotyczą bezpośrednio nas czy naszych sojuszników” ale „trzeba zrobić co się da, żeby się wycofać z Iraku”, ponieważ taka wojna jak iracka "to są wojny kolonialne”. Natomiast Dobrosz stwierdził: „Próbujmy zrobić wszystko, żeby ta interwencja w Iraku otrzymała oficjalny status Organizacji Narodów Zjednoczonych"33.

\section{Zakończenie}

Liga Polskich Rodzin miała dwojakie podejście do polityki Stanów Zjednoczonych. $Z$ jednej strony uważała się za ugrupowanie proamerykańskie, uważające sojusz z USA za jedną z podstaw polskiej polityki zagranicznej. Swoje stanowisko uzasadniała faktem, że dzięki współpracy z amerykańskim mocarstwem Rzeczpospolita mogła zachować swoją suwerenności i integralność terytorialną przed niemieckim rewizjonizmem oraz rosyjskim dążeniem do odbudowania dawnej strefy wpływów w Europie środkowo-wschodniej. Innym argumentem przemawiającym za zbliżeniem polsko-amerykańskim miało być przekonanie, że dzięki tej współpracy Polska zyska znacznie większe profity ekonomiczne niż mogłaby zdobyć poprzez integrację z Unią Europejską. Stany Zjednoczone stanowily więc dla Ligi lepszą alternatywę od Unii, gdyż, jak sądzili przywódcy ugrupowania, wspierali swoich sojuszników bez narzucania im dyktatu w polityce wewnętrznej. Trzecim, równie istotnym powodem proamerykańskiego spojrzenia LPR była nadzieja, że dzięki statusowi głównego sojusznika USA w kontynentalnej Euro-

32 Nie jesteśmy chtopcem..., s. 26; Dlaczego mamy się bić..., s. 2; Nasza rolą..., s. 4; wystąpienie M. Giertycha, IV kad., pos. 40 Sejmu...; wystąpienie Z. Wrzodaka, IV kad., pos. 44 Sejmu...; wystąpienie Z. Wrzodaka, IV kad., pos. 62 Sejmu...; wystąpienie J. Dobrosza, IV kad., pos. 67 Sejmu...; wystąpienie Z. Wrzodaka, IV kad., pos. $65 \mathrm{KON}$...; wystąpienie Z. Wrzodaka, IV kad., pos. $120 \mathrm{KON}$...; wystąpienie M. Giertycha, IV kad., pos. $138 \mathrm{KSZ}$ z 10 XII 2003, Sejm RP, http:// orka.sejm.gov.pl/SQL.nsf/Main4?OpenForm\&SZA [odczyt 3 II 2011].

33 Naszą rola..., s. 4; wystąpienie J. Dobrosza, IV kad., pos. 67 Sejmu.... 
pie Rzeczpospolita zyska większe znaczenie wśród państw Starego Kontynentu a w momencie negocjacji akcesyjnych z UE będzie mogła wywalczyć sobie znacznie lepsze warunki i pozycję w jej strukturach.

$\mathrm{Z}$ drugiej strony jednakże przywódcy Ligi zdawali sobie sprawę, że wiele z ich postulatów ma charakter myślenia życzeniowego, nie opartego na realnej ocenie sytuacji i celów amerykańskiej polityki. Jako dowód przytaczali fakt złego traktowania Polski i Polaków przez Stany Zjednoczone i ignorowania albo naruszania jej interesów. Do takich działań zaliczali chociażby wykorzystywanie wojsk polskich w misjach wojskowych w Afganistanie i Iraku bez jakiejkolwiek rekompensaty ze swojej strony w postaci wsparcia materialnego, poparcia politycznego w różnych sporach międzynarodowych lub zniesienia wiz dla polskich obywateli. Dlatego też deklarowane poparcie dla Stanów Zjednoczonych mieszało się z krytyką ich polityki w sprawach szczegółowych, chociaż zawsze Liga stała na stanowisku popierania USA, uważając sojusz z nimi za znacznie lepsze rozwiązanie niż akcesję do UE. 